\title{
Dialyzer Reuse and Mortality Risk in Patients with End-Stage Renal Disease: A Systematic Review
}

\author{
Tais Freire Galvao ${ }^{a, b}$ Marcus Tolentino Silva ${ }^{a, c} \quad$ Maria Elizete de Almeida Araujo ${ }^{b}$ \\ Wilson Seffair Bulbol ${ }^{b}$ Angela Libia de Melo Pereira Cardoso ${ }^{d}$ \\ ${ }^{a}$ Faculty of Medicine, University of Brasilia, Brasilia, ${ }^{b}$ Getulio Vargas University Hospital, Federal University of \\ Amazonas, Manaus, ' ${ }^{C}$ Ministry of Health, Department of Science and Technology, Brasilia, and ${ }^{\mathrm{d}}$ Faculty of \\ Pharmaceutical Sciences, Federal University of Amazonas, Manaus, Brazil
}

\section{Key Words}

Mortality $\cdot$ Dialysis $\cdot$ Dialyzer $\cdot$ Reuse $\cdot$ Chronic kidney

failure $\cdot$ Systematic review

\begin{abstract}
Background and Aim: Robust evidence about dialyzer reuse effects on mortality is not available. Our aim was to summarize the evidence for the effectiveness of dialyzer reuse compared to single use in patients with end-stage renal disease. Methods: We searched MEDLINE, Embase, CINAHL, SciELO, LILACS, USRDS ADR, universities' theses databases and annals of congress from major nephrology societies. Reviewers performed the study selection and data extraction independently. We used the GRADE approach to assess the quality of the evidence. Mortality was the primary outcome. Results: A total of 1,190 studies were retrieved, and 14 were included in the review ( $n=956,807$ patients). The disinfectants used on dialyzer reprocessing were hypochlorite, formaldehyde, glutaraldehyde, and peracetic acid. The evidence available from the studies was of very low quality. Most studies found no differences between groups. In studies with statistically significant differences, these differences were not observed in all groups and they varied by the type of disinfectant, time of observation and treatment unit. Conclusions: No significant differences were identified for the superiority or inferi-
\end{abstract}

ority of dialyzer reuse versus single use when assessing the mortality of patients with end-stage renal disease. Studies of higher quality, including randomized clinical trials, are required to provide conclusive evidence regarding the effectiveness and safety of dialyzer reuse.

Copyright $\odot 2012$ S. Karger AG, Basel

\section{Introduction}

Dialyzer reuse in patients with end-stage renal disease has been employed since 1960 [1]. According to reports, the practice of dialyzer reuse in the USA is decreasing [2, 3]. The largest US dialysis provider, Fresenius Medical Care discontinued reuse in the 2000s, in a combined own product manufacturing and renal care chain $[4,5]$. This trend is likely due to the availability of less expensive high-flux, single-use dialyzers, greater compatibility of the synthetic membranes, and alternative sterilization methods that avoid first-use syndrome [5]. However, other large providers - like DaVita and smaller ones - still reuse dialyzers [6]. In lower resource settings, dialyzer reuse is predominant $[7,8]$.

To our knowledge, systematic reviews of this issue are not available. Narrative reviews recognize the lack of conclusive evidence regarding the effects of dialyzer reuse on

\section{KARGER}

Fax +41613061234 E-Mail karger@karger.ch www.karger.com
(C) 2012 S. Karger AG, Basel

0250-8095/12/0353-0249\$38.00/0

Accessible online at:

www.karger.com/ajn
Tais Freire Galvao

Universidade de Brasilia, Campus Universitario

Faculdade de Medicina, Asa Norte

Brasilia, DF 70910-900 (Brazil)

Tel. +55 613107 1894, E-Mail taisgalvao@gmail.com 
mortality [5, 9-13]. Some have noted the benefits of reducing costs and waste disposal with reuse $[5,9,11-13]$, and others have highlighted the concerns for increased risks with reuse, including adverse reactions, changes in membrane permeability or potential technique errors $[9$, $10,12,13]$. However, the effectiveness of dialyzer reuse has not yet been established, and uncertainties about the effect of this practice on the morbidity and mortality of patients remain unsolved.

The objective of this study was to evaluate the effect of dialyzer reuse on the mortality of patients with end-stage renal disease compared to patients with single use of dialyzers through a systematic review of the literature.

\section{Materials and Methods}

\section{Studies Eligibility Criteria}

We considered eligible controlled studies that compared patients with end-stage renal disease on hemodialysis using dialyzers reprocessed by any sterilization technique to patients with single-use dialyzers. There were no restrictions on language, length of follow-up, or publication date or status.

\section{Information Sources and Search Strategy}

We searched MEDLINE, Embase, the Cumulative Index to Nursing and Allied Health Literature (CINAHL), the Latin American and Caribbean Center on Health Sciences Information (LILACS), Scientific Electronic Library Online (SciELO), United States Renal Data System 2011 Annual Data Report (USRDS ADR), universities' theses databases and the annals of congress of major nephrology societies (the American Society of Nephrology, the Brazilian Society of Nephrology, the Canadian Society of Nephrology, the European Renal Association-European Dialysis and Transplant Association, the International Society of Nephrology, the Latin American Society of Nephrology and the World Congress of Nephrology). The search on gray literature was included to identify and avoid publication bias. We screened the references of the relevant articles to identify potentially eligible studies and contacted experts to identify those studies that could not be located or were under development. The last literature search was conducted in January 2012.

The search strategy used in MEDLINE (via PubMed) was: ('renal dialysis' [tiab] or 'renal dialyses' [tiab] or 'hemodialysis' [tw] or 'hemodialyses' $[\mathrm{tw}$ ] or 'extracorporeal dialyses' $[\mathrm{tw}]$ or 'dialysis' $[\mathrm{tw}]$ ) and ('equipment reuse' $[\mathrm{tw}]$ or 'reuse' $[\mathrm{tw}]$ or 'product recycling' $[t w]$ or 'disinfection'[mesh] or 'disinfection' $[t w]$ or 'sterilization' [mesh] or 'sterilization' $[\mathrm{tw}]$ ) and ('acetic acid' $[\mathrm{tw}]$ or 'renalin' $[\mathrm{tw}]$ or 'chlorine' $[\mathrm{tw}]$ or 'citric acid' $[\mathrm{tw}]$ or 'citrate' $[\mathrm{tw}]$ or 'formaldehyde' $[\mathrm{tw}]$ or 'methanal' $[\mathrm{tw}]$ or 'formol' $[\mathrm{tw}]$ or 'formalin' $[\mathrm{tw}]$ or 'glutaraldehyde' $[\mathrm{tw}]$ or 'glutardialdehyde' $[\mathrm{tw}$ ] or 'glutarol' $[\mathrm{tw}]$ or 'hydrogen peroxide' [tw] or 'hydroperoxide' [tw] or 'peroxyacetic acid' $[\mathrm{tw}]$ or 'peroxyethanoic acid' $[\mathrm{tw}]$ or proxitane $[\mathrm{tw}]$ or 'peroxides' $[\mathrm{tw}]$ or 'sodium hypochlorite'[tw] or 'disinfectant' $[\mathrm{tw}]$ or 'disinfectants' $[\mathrm{tw}]$ or 'biocides' $[\mathrm{tw}]$ or 'membranes, artificial' [mesh] or 'membrane' $[\mathrm{tw}]$ or 'artificial membranes' $[\mathrm{tw}]$ or 'artificial membrane' $[\mathrm{tw}]$ or 'polymers' [mesh] or 'polymers' $[\mathrm{tw}]$ or 'sulfones'[mesh] or 'sulfones' $[\mathrm{tw}]$ or 'polysulfone' $[\mathrm{tw}]$ or 'cellulose' $[\mathrm{tw}])$. Modifications of this strategy were applied when searching the other databases.

\section{Study Selection and Data Extraction}

Four pairs of researchers independently reviewed the retrieved study titles and abstracts. The full texts were obtained if it was not possible to assess the eligibility. Three researchers (M.E.A.A., M.T.S. and T.F.G.) checked all selected articles. We completed a data extraction sheet to obtain the data of interest. One author extracted the data (T.F.G.), and the other two confirmed the extraction (M.E.A.A., M.T.S.). Disagreements were resolved by a consensus between the authors.

We extracted the following variables: year, country, funding sources, study design, population, history of dialysis (incident or prevalent), adjusted variables, type of dialyzer, membrane permeability, type of disinfectant, reprocessing technique, number of reprocesses, type of healthcare unit (free-standing or hospital), type of analysis (intention-to-treat or per protocol), sample size and mortality risk. If any data were not available in the paper, we attempted to contact the corresponding author of the study.

Adjusted variables were labeled as demographics (e.g. age, gender or race), cause of renal failure, vintage (time on dialysis treatment), facility (e.g. dialyzer reuse technique, number of reuses, formaldehyde concentration, dialysis unit size, unit age, high-flux dialyzer, type of dialysate, water treatment, facility-standardized mortality ratio, facility profit status, germicide type), and comorbidities (e.g. hypertension, neoplasia).

For the USRDS ADR 2011, we collected data from ESRD Chapter 10 - Providers. Patients treated on Fresenius Medical Care and Dialysis Clinic Inc. (DCI) were considered as single use, and patients treated on DaVita were considered as reuse $(\geq 75 \%$ patients are treated on reuse). This information was confirmed by contacting the providers and authors of studies performed on such providers.

\section{Data Analysis}

The primary outcomes in this review included relative risks (RRs), hazard ratios (HRs), odds ratios (ORs) of mortality or standardized mortality ratios (SMRs) and the respective 95\% confidence intervals (95\% CIs). The threshold for significance was a two-tailed $\mathrm{p}<0.05$.

Due to the differences between the study measures and significant heterogeneity, meta-analyses were not performed.

\section{Quality and Risk of Bias Assessment}

We used the Grading of Recommendations Assessment, Development and Evaluation (GRADE) approach to assess the quality of the studies [14]. This method rates the quality of evidence as high, moderate, low or very low. For observational studies, we evaluated: study limitations (that is, the failure to develop and apply appropriate eligibility criteria, flawed measurement of both exposure and outcome, the failure to adequately control confounding, the failure to accurately measure all known prognostic factors or an incomplete, inadequately short follow-up), imprecision, inconsistency, indirectness of evidence, publication bias, and factors that could increase the quality of the evidence (e.g. a large magnitude of effect or confounding would reduce the demonstrated effect). The quality assessment was considered when interpreting the findings. 
Fig. 1. Flowchart of the search, selection and inclusion of studies.

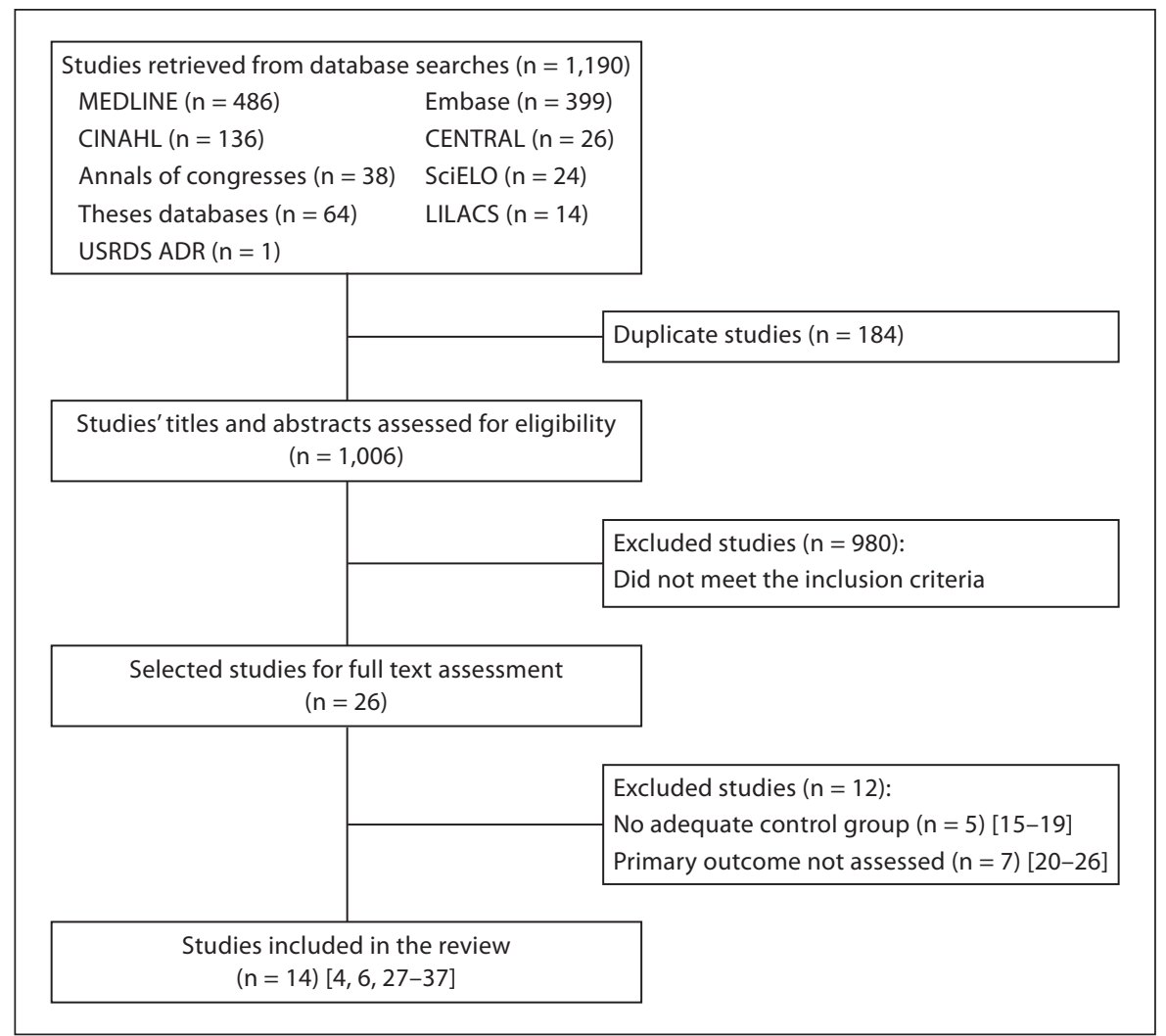

\section{Results}

Our literature search identified 1,190 articles (fig. 1). By screening the titles and abstracts, 980 records were excluded. We analyzed the full texts of the remaining publications, and 14 were included in the review ( $\mathrm{n}=$ 956,807 patients).

\section{Characteristics of the Included Studies}

All studies included in the review took place in the USA with the exception of one performed in Taiwan [36]. Most studies were conducted in the 1980s and 1990s. In these decades, conventional dialyzers were predominantly employed; however, in most articles, the type of dialyzer used was not clearly stated (table 1 ).

The disinfectants used in reprocessing comprised hypochlorite, formaldehyde, glutaraldehyde, and peracetic acid. Five studies reported using both manual and automated techniques for dialyzer reprocessing $[28,30,32,33$, 36 . The average number of reuses ranged from 2.54 [36] to 15 [33]. Some data were obtained by contacting the corresponding authors of the studies.

Dialyzer Reuse and Mortality Risk
Most studies were designed as retrospective cohorts that used patient records available from the clinical databases of health insurance companies, mainly Medicare (table 2). Only one study had a sample size of less than 1,000 patients [36]. Five studies were prospective, including four cohorts $[4,28,33,36]$ and one single crossover [37]. In 5 studies, the patients included were not on renal replacement therapy before the data collection period (incident population) $[4,27,31,35,36]$. Most studies used an intention-to-treat model to analyze mortality, although this information was not available or clearly stated in some studies. The adjustment models varied widely across studies.

\section{Quality of Evidence}

The evidence was classified as very low quality using the GRADE approach (table 3). The evidence from studies was rated down from low (observational design) to very low. Studies failed on limitations and inconsistency across study methods and results. Because a formal meta-analysis was not possible, statistical heterogeneity could not be assessed. Publication bias was not detected, but it is worth mentioning that studies sponsored by 
Table 1. Main characteristics of included studies

\begin{tabular}{|c|c|c|c|c|c|c|}
\hline Study & Country & Year & $\begin{array}{l}\text { Health unit } \\
\text { type }\end{array}$ & Dialyzer type & $\begin{array}{l}\text { Membrane } \\
\text { permeability }\end{array}$ & Disinfectant (available rate of use) \\
\hline Held [27] & USA & $1977-1981$ & $\begin{array}{l}\text { hospital and } \\
\text { freestanding }\end{array}$ & conventional $^{\mathrm{a}}$ & low flux ${ }^{\mathrm{a}}$ & $\mathrm{b}$ \\
\hline Held [28] & USA & 1989-1990 & freestanding & conventional & low flux & $\begin{array}{l}\text { formaldehyde (56\%), glutaraldehyde (6\%), peracetic acid } \\
(39 \%)^{\mathrm{a}}\end{array}$ \\
\hline Feldman [29] & USA & 1986-1987 & $\begin{array}{l}\text { hospital and } \\
\text { freestanding }\end{array}$ & conventional & low flux & $\begin{array}{l}\text { formaldehyde ( } 59 \% \text { in } 1986,61 \% \text { in } 1987) \text {, glutaraldehyde } \\
\text { ( } 0.9 \text { to } 1.9 \% \text { in } 1986,1.7 \text { to } 3 \% \text { in } 1987) \text {, peracetic acid ( } 29 \% \\
\text { in } 1986,35 \% \text { in } 1987)\end{array}$ \\
\hline Collins [30] & USA & 1989-1993 & $\begin{array}{l}\text { hospital and } \\
\text { freestanding }\end{array}$ & conventional & low flux & $\begin{array}{l}\text { 1991-1993: formaldehyde }(28.3 \%) \text {, } \\
\text { glutaraldehyde }(24.3 \%) \text {, peracetic acid }(3.8 \%)\end{array}$ \\
\hline Feldman [31] & USA & $1986-1987$ & freestanding & $\mathrm{b}$ & $\mathrm{b}$ & $\begin{array}{l}\text { formaldehyde }(70 \%) \text {, glutaraldehyde }(3.7 \%) \text {, peracetic acid } \\
(26.3 \%)\end{array}$ \\
\hline Ebben [32] & USA & 1991-1995 & $\begin{array}{l}\text { hospital and } \\
\text { freestanding, } \\
\text { for profit and } \\
\text { not for profit }\end{array}$ & $\begin{array}{l}\text { synthetic and } \\
\text { conventional }\end{array}$ & $\begin{array}{l}\text { low flux and } \\
\text { high flux }\end{array}$ & formaldehyde, glutaraldehyde, peracetic acid \\
\hline Port [33] & USA & 1994-1995 & $\begin{array}{l}\text { hospital and } \\
\text { freestanding, } \\
\text { for profit and } \\
\text { not for profit }\end{array}$ & $\begin{array}{l}\text { synthetic, } \\
\text { substituted } \\
\text { cellulose and } \\
\text { conventional }\end{array}$ & $\begin{array}{l}\text { low flux and } \\
\text { high flux }\end{array}$ & $\begin{array}{l}\text { formaldehyde (35\%), hypochlorite }(31 \%) \text {, } \\
\text { glutaraldehyde }(6 \%) \text {, peracetic acid (38\%) }\end{array}$ \\
\hline Collins [34] & USA & 1998-1999 & $\begin{array}{l}\text { hospital and } \\
\text { freestanding }\end{array}$ & $\begin{array}{l}\text { synthetic and } \\
\text { conventional }^{\mathrm{a}}\end{array}$ & $\begin{array}{l}\text { low flux and } \\
\text { high flux }\end{array}$ & $\begin{array}{l}\text { formaldehyde }(30 \%) \text {, hypochlorite }(34 \%) \text {, } \\
\text { glutaraldehyde }(6 \%) \text {, peracetic acid }(49 \%)^{\mathrm{a}}\end{array}$ \\
\hline Lowrie [4] & USA & 2001 & freestanding ${ }^{\mathrm{a}}$ & synthetic & $\mathrm{b}$ & $\begin{array}{l}\text { formaldehyde with hypochlorite }(75 \%) \text {, glutaraldehyde }(1 \%) \text {, } \\
\text { peracetic acid }(19 \%) \text {, citric acid }(1 \%) \text {, heat }(<1 \%)\end{array}$ \\
\hline Fan [35] & USA & $2000-2001$ & $\begin{array}{l}\text { hospital and } \\
\text { freestanding, } \\
\text { for profit and } \\
\text { not for profit }\end{array}$ & $\begin{array}{l}\text { synthetic and } \\
\text { conventional }^{\mathrm{a}}\end{array}$ & b & $\mathrm{b}$ \\
\hline Chuang [36] & Taiwan & 2005 & hospital & $\begin{array}{l}\text { reuse: synthetic } \\
\text { single use: } \\
\text { synthetic and } \\
\text { substituted } \\
\text { cellulose }\end{array}$ & $\mathrm{b}$ & peracetic acid \\
\hline Lacson [37] & USA & 2007 & freestanding & synthetic ${ }^{c}$ & high flux ${ }^{c}$ & peracetic acid \\
\hline Bond [6] & USA & 2009 & freestanding $^{c}$ & synthetic & high flux ${ }^{c}$ & peracetic acid \\
\hline USRDS [38] & USA & 2009 & $\begin{array}{l}\text { hospital and } \\
\text { freestanding }\end{array}$ & $\mathrm{b}$ & $\mathrm{b}$ & $\mathrm{b}$ \\
\hline
\end{tabular}

Conventional $=$ Cellulose; substituted cellulose $=$ cellulose triacetate, cellulose acetate; synthetic $=$ polyacrylonitrile, polysulfone, polyamide, polycarbonate, polymethylmethacrylate, polyarylethersulfone, polyvinylpyrrolidone.

${ }^{a}$ Data inferred or calculated by the authors from information available in the studies. ${ }^{b}$ Data not reported in the study or not obtained by contacting the corresponding author of the study. ${ }^{c}$ Data obtained by contacting the corresponding author of the study.

manufacturers of disinfectants showed no significant results $[30,32,34,35]$, whereas studies sponsored by manufacturers of dialyzers showed a reduced risk of mortality when comparing single dialyzer use with reuse $[4,37]$ (table 4).

\section{Mortality}

The mortality risk results are presented in table 4 and were obtained as the RRs, HRs or ORs of reuse (exposed) versus single use (nonexposed). However, 3 studies [4, 36, 37] calculated such risks by single use (nonexposed) related to reuse (exposed). The risk results were obtained 
Table 2. Analytical features of the studies

\begin{tabular}{|c|c|c|c|c|c|c|c|}
\hline Study & $\begin{array}{l}\text { Reuse } \\
(\mathrm{n})\end{array}$ & $\begin{array}{l}\text { Single use } \\
\text { (n) }\end{array}$ & $\begin{array}{l}\text { History of } \\
\text { dialysis }\end{array}$ & Study design & Analysis approach & Adjusted variables & Funding \\
\hline Held [27] & $2,097^{\mathrm{a}}$ & $2,564^{\mathrm{a}}$ & incident & $\begin{array}{l}\text { retrospective } \\
\text { cohort }\end{array}$ & per protocol ${ }^{\mathrm{a}}$ & comorbidities & health department \\
\hline Held [28] & 53,634 & 12,463 & prevalent & $\begin{array}{l}\text { prospective } \\
\text { cohort }\end{array}$ & per protocol ${ }^{\mathrm{a}}$ & $\begin{array}{l}\text { demographics, cause of renal failure, } \\
\text { standardized mortality ratio and facility }\end{array}$ & health department \\
\hline Feldman [29] & 20,316 & 7,622 & prevalent & $\begin{array}{l}\text { retrospective } \\
\text { cohort }\end{array}$ & intention to treat & $\begin{array}{l}\text { demographics, cause of renal failure, } \\
\text { and facility }\end{array}$ & $\begin{array}{l}\text { agency for research } \\
\text { funding }\end{array}$ \\
\hline Collins [30] & total sample: & $13,551^{b, c}$ & prevalent & $\begin{array}{l}\text { retrospective } \\
\text { cohort }\end{array}$ & intention to treat ${ }^{\mathrm{a}}$ & $\begin{array}{l}\text { demographics, comorbidities and } \\
\text { facility }\end{array}$ & $\begin{array}{l}\text { agency for research } \\
\text { funding and } \\
\text { disinfectant } \\
\text { manufacturer }\end{array}$ \\
\hline Feldman [31] & 1,241 & 250 & incident & $\begin{array}{l}\text { retrospective } \\
\text { cohort }\end{array}$ & intention to treat ${ }^{\mathrm{a}}$ & $\begin{array}{l}\text { demographics, cause of renal failure } \\
\text { and predictors }(\mathrm{p}<0.20)\end{array}$ & $\begin{array}{l}\text { agency for research } \\
\text { funding }\end{array}$ \\
\hline Ebben [32] & total sample: & $374,744^{\mathrm{b}}$ & prevalent & $\begin{array}{l}\text { retrospective } \\
\text { cohort }\end{array}$ & intention to treat $\mathrm{t}^{\mathrm{a}}$ & $\begin{array}{l}\text { demographics, cause of renal failure, } \\
\text { vintage, comorbidities and facility }\end{array}$ & $\begin{array}{l}\text { disinfectant } \\
\text { manufacturer }\end{array}$ \\
\hline Port [33] & 10,161 & 2,630 & prevalent & $\begin{array}{l}\text { prospective } \\
\text { cohort }\end{array}$ & intention to treat ${ }^{\mathrm{a}}$ & $\begin{array}{l}\text { demographics, comorbidities and } \\
\text { facility }\end{array}$ & health department \\
\hline Collins [34] & 42,222 & 7,051 & incident & $\begin{array}{l}\text { retrospective } \\
\text { cohort }\end{array}$ & $\mathrm{b}$ & $\begin{array}{l}\text { demographics, comorbidities and } \\
\text { facility }\end{array}$ & $\begin{array}{l}\text { disinfectant } \\
\text { manufacturer }\end{array}$ \\
\hline Lowrie [4] & 52,985 & 18,137 & prevalent & $\begin{array}{l}\text { prospective } \\
\text { cohort }\end{array}$ & per protocol ${ }^{\mathrm{a}}$ & $\begin{array}{l}\text { demographics, cause of renal failure, } \\
\text { facility and predictors }(p<0.01)\end{array}$ & $\begin{array}{l}\text { dialyzer } \\
\text { manufacturer }\end{array}$ \\
\hline Fan [35] & 61,391 & 14,440 & incident & $\begin{array}{l}\text { retrospective } \\
\text { cohort }\end{array}$ & intention to treat & $\begin{array}{l}\text { demographics, cause of renal failure, } \\
\text { comorbidities and facility }\end{array}$ & $\begin{array}{l}\text { disinfectant } \\
\text { manufacturer }\end{array}$ \\
\hline Chuang [36] & 446 & 376 & incident & $\begin{array}{l}\text { prospective } \\
\text { cohort }\end{array}$ & intention to treat & demographics and comorbidities & heath care facility \\
\hline Lacson [37] & 1,259 & 1,354 & prevalent & $\begin{array}{l}\text { single } \\
\text { crossover }\end{array}$ & intention to treat ${ }^{\mathrm{d}}$ & $\begin{array}{l}\text { demographics, vintage and } \\
\text { comorbidities }\end{array}$ & $\begin{array}{l}\text { dialyzer } \\
\text { manufacturer }\end{array}$ \\
\hline Bond [6] & 10,182 & 17,223 & prevalent & $\begin{array}{l}\text { retrospective } \\
\text { cohort }\end{array}$ & intention to treat ${ }^{\mathrm{d}}$ & $\begin{array}{l}\text { demographics, cause of renal failure, } \\
\text { vintage and comorbidities }\end{array}$ & heath care facility \\
\hline USRDS [38] & $110,299^{\mathrm{e}}$ & $135,239^{\mathrm{f}}$ & prevalent & $\begin{array}{l}\text { retrospective } \\
\text { cohort }\end{array}$ & intention to treat ${ }^{\mathrm{a}}$ & $\begin{array}{l}\text { demographics, cause of renal failure } \\
\text { and vintage }\end{array}$ & health department \\
\hline
\end{tabular}

${ }^{a}$ Data calculated or inferred by the authors from information available in the report. ${ }^{b}$ Data not reported in the study or not obtained after contacting the corresponding author of the study. ${ }^{\mathrm{C}}$ Data refers to the $1991-1993$ period to avoid duplication of data from Held et al. [28]. ${ }^{\mathrm{d}}$ Data obtained by contacting the corresponding author of the study. ${ }^{\mathrm{e}}$ Patients treated on Da Vita. ${ }^{\mathrm{f}}$ Patients treated on Fresenius and DCI.

from the available adjusted data. One study calculated SMRs from different providers using traditional SMR calculation method [38].

The majority of the studies revealed no statistically significant differences in mortality between dialyzer single use and reuse. The most comprehensive provider level comparison, the USRDS ADR 2011 (245,538 patients treated in 2009, adjusted for the same confounding), found similar results in SMR of patients treated by providers that employ only single use (Fresenius and DCI) and patients treated on DaVita, considered as reuse [38]. However, patients on reuse (treated on DaVita) had a statistically significant slight reduction in SMR (SMR 0.97; 95\% CI 0.99-0.96).

Even in studies where a statistically significant difference was identified, it was not observed in all groups and varied by the type of disinfectant, the length of follow-up and the health care facility (free standing or hospital) [4, 27-30]. In one study, the single use of dialyzers significantly increased the risk of death compared to reuse, but different inclusion criteria were applied for patients in the reuse and single use groups, resulting in a statistically significant healthier patient profile in the reuse group [36]. 
Table 3. Quality of evidence profile for mortality outcome, adapted from GRADE [14]

\begin{tabular}{|c|c|c|c|c|c|c|c|}
\hline $\begin{array}{l}\text { Number of } \\
\text { studies }\end{array}$ & Design & Study limitations (risk of bias) & Inconsistency & Indirectness & Imprecision & $\begin{array}{l}\text { Publication } \\
\text { bias }\end{array}$ & Quality \\
\hline $\begin{array}{l}\text { Fourteen } \\
{[4,6,27-38]}\end{array}$ & $\begin{array}{l}\text { observational } \\
\text { studies: cohort } \\
\text { and single } \\
\text { crossover }\end{array}$ & $\begin{array}{l}\text { very serious: failure to control for } \\
\text { potential confounding factors; failure } \\
\text { to accurately measure all known } \\
\text { prognostic factors }\end{array}$ & $\begin{array}{l}\text { very serious: hetero- } \\
\text { geneous methods and } \\
\text { results across studies }{ }^{\mathrm{a}}\end{array}$ & $\begin{array}{l}\text { no serious } \\
\text { indirectness }\end{array}$ & $\begin{array}{l}\text { no serious } \\
\text { imprecision }^{\mathrm{b}}\end{array}$ & undetected $^{\mathrm{c}}$ & very low \\
\hline
\end{tabular}

a Statistical heterogeneity was not assessed through meta-analysis estimates, just from qualitative comparisons. Studies assessed different populations (incident and prevalent on dialysis), types of membrane, types of disinfectants, and health care facilities. ${ }^{\mathrm{b}}$ Quality was not reduced due to imprecision, but most studies had imprecise estimates. ${ }^{c}$ Quality was not reduced due to publication bias, but studies sponsored by dialyzer manufacturers showed significant results favoring single use, while studies sponsored by disinfectant manufacturers showed nonsignificant results.

\section{Discussion}

Economic savings, along with less waste disposal, are the main reasons to reuse dialyzers $[5,9,11-13]$. Most countries of lower income employ reuse in $100 \%$ patients in renal replacement therapy $[7,8]$. In developing countries that do not reprocess dialyzers, reuse is highlighted as an alternative to handle with health care delivery costs $[39,40]$. Conversely, dialyzer reuse is prone to increase morbidity due to risks of infection and pyrogenic reaction, but no evidence of such associations is available [41, 42]. To ensure safety of the reprocessing technique, renal replacement therapy providers should follow existing recommended practices and guidelines [43, 44]. Such standards are central to infection control and quality guarantee in renal care with dialyzer reuse.

We decided to study mortality to assess the effectiveness of dialyzer reuse on patients' health since it is a patient-centered and hard outcome. End-stage renal disease morbidity can be assessed from heterogeneous, widevariant methods. Renal function and clearance markers, length of hospital stay, and immunological response are the most common ones [13, 25, 45]. But it is worth to say that there is a rising concern in using surrogate outcomes in medical research, as such outcomes can be misleading [46].

The effectiveness of dialyzer reuse was not confirmed by the studies included in this review. Some studies identified statistically significant difference in mortality between dialyzer reuse and single use in some groups analyzed, but such differences were not consistent across all groups. The USRDS universal reporting system, the most ample provider-level comparison, found a slightly reduced mortality in patients treated by a provider that reuses dialyzers in most patients.
Morbidity, in contrast, could be influenced by reuse technique risks, such as pyrogenic reactions and infections. Since these risks could be controlled by dialysis facilities staff, training is an important way to mitigate the hazard. Team approach, staff education, and communication were shown to be vital to the success of dialyzer reuse [47].

A major limitation of this review is the observational design that was used in all included studies. The definition of nonrandom groups undermines the comparability of subjects. Important prognostic factors, such as age and the primary cause of chronic disease, can influence the allowance of reuse or single use of dialyzers or switching for patients on renal replacement therapy [48]. The heterogeneous distribution of risk factors between the groups reduces the validity of the results. To allow confidence for decision-making process, our search was extensive and quite sensitive, including databases of indexed papers and governmental and other nonindexed literature (gray literature).

Most of the observed effects in selected cohort studies may be due to immortal time bias (also termed as survivor selection bias or survival bias) [49]. This bias denotes a length of time in the follow-up period of a cohort during which the outcome under study could not have occurred. The presence of immortal time bias is proven to underestimate the risk measures and overestimate the effect, in this review, mortality $[49,50]$. Included studies that used databases as source of information are susceptible to immortal time bias, since most databases only consider hemodialysis individuals who survived more than 90 days of treatment. This 'immortality' time was not possible to be assessed in such studies.

Some techniques can be used to improve the comparability of the research groups and to avoid immortal time bias, such as restriction of categories, matching, and 
Table 4. Mortality risks of reuse compared to single use

\begin{tabular}{|c|c|c|c|c|c|c|}
\hline \multirow[t]{2}{*}{ Study } & \multicolumn{3}{|l|}{ Subgroups of analysis } & \multirow{2}{*}{$\begin{array}{l}\text { Relative } \\
\text { risk }\end{array}$} & \multirow[t]{2}{*}{$95 \% \mathrm{CI}$} & \multirow{2}{*}{$\begin{array}{l}\mathrm{p} \\
\text { value }\end{array}$} \\
\hline & disinfectant type & facility type & other subgroups & & & \\
\hline Held [27] & & & $\begin{array}{l}\text { multiple uses started } \\
\text { at or prior to } 1980 \\
\text { multiple uses started } \\
\text { after } 1980\end{array}$ & $\begin{array}{l}0.88 \\
1.01\end{array}$ & $\begin{array}{l}\text { n.r. } \\
\text { n.r. }\end{array}$ & $\begin{array}{l}<0.03 \\
<0.88\end{array}$ \\
\hline Held [28] & $\begin{array}{l}\text { formaldehyde } \\
\text { glutaraldehyde } \\
\text { peracetic acid }\end{array}$ & & & $\begin{array}{l}1.06^{\mathrm{a}} \\
1.17^{\mathrm{a}} \\
1.13^{\mathrm{a}}\end{array}$ & $\begin{array}{l}0.99-1.14 \\
1.04-1.31 \\
1.06-1.21\end{array}$ & $\begin{array}{r}0.088 \\
0.010 \\
<0.001\end{array}$ \\
\hline Feldman [29] & $\begin{array}{l}\text { formaldehyde } \\
\text { glutaraldehyde } \\
\text { peracetic acid }\end{array}$ & $\begin{array}{l}\text { hospital } \\
\text { freestanding } \\
\text { hospital } \\
\text { freestanding } \\
\text { hospital } \\
\text { freestanding }\end{array}$ & & $\begin{array}{l}1.06^{\mathrm{a}} \\
1.03^{\mathrm{a}} \\
1.09^{\mathrm{a}} \\
1.13^{\mathrm{a}} \\
0.95^{\mathrm{a}} \\
1.10^{\mathrm{a}}\end{array}$ & $\begin{array}{l}0.98-1.15 \\
0.96-1.10 \\
0.71-1.67 \\
0.95-1.35 \\
0.85-1.06 \\
1.02-1.18\end{array}$ & $\begin{array}{l}0.12 \\
0.45 \\
0.70 \\
0.18 \\
0.40 \\
0.02\end{array}$ \\
\hline Collins [30] & $\begin{array}{l}\text { formaldehyde } \\
\text { glutaraldehyde } \\
\text { peracetic acid }\end{array}$ & $\begin{array}{l}\text { hospital } \\
\text { freestanding } \\
\text { hospital } \\
\text { freestanding } \\
\text { hospital } \\
\text { freestanding }\end{array}$ & & $\begin{array}{l}1.15^{\mathrm{b}} \\
0.82^{\mathrm{b}} \\
1.09^{\mathrm{b}} \\
1.03^{\mathrm{b}} \\
0.94^{\mathrm{b}} \\
0.83^{\mathrm{b}}\end{array}$ & $\begin{array}{l}0.86-1.55 \\
0.72-0.93 \\
0.74-1.59 \\
0.80-1.33 \\
0.67-1.32 \\
0.72-0.96\end{array}$ & $\begin{array}{l}\text { n.r. } \\
\text { n.r. } \\
\text { n.r. } \\
\text { n.r. } \\
\text { n.r. } \\
\text { n.r. }\end{array}$ \\
\hline Feldman [31] & $\begin{array}{l}\text { formaldehyde, glutaraldehyde and } \\
\text { peracetic acid }\end{array}$ & & & 1.25 & $1.03-1.52$ & 0.023 \\
\hline Ebben [32] & $\begin{array}{l}\text { formaldehyde, glutaraldehyde and peracetic } \\
\text { acid }\end{array}$ & & & n.r. ${ }^{c}$ & n.s. & n.r. \\
\hline Port [33] & $\begin{array}{l}\text { formaldehyde, glutaraldehyde, peracetic acid } \\
\text { and hypochlorite }\end{array}$ & & & 0.96 & $0.86-1.08$ & 0.51 \\
\hline Collins [34] & $\begin{array}{l}\text { formaldehyde } \\
\text { glutaraldehyde, peracetic acid and hypochlorite }\end{array}$ & & & $\begin{array}{l}1.01 \\
\text { n.r. }\end{array}$ & $\begin{array}{l}0.92-1.11 \\
\text { n.s. }\end{array}$ & $\begin{array}{l}\text { n.r. } \\
\text { n.r. }\end{array}$ \\
\hline Lowrie [4] & & & $\begin{array}{l}\text { day } 0 \\
\text { after } 30 \text { days } \\
\text { after } 60 \text { days } \\
\text { after } 90 \text { days } \\
\text { after } 120 \text { days }\end{array}$ & $\begin{array}{l}\text { HR } 0.95^{\mathrm{d}} \\
\text { HR } 0.09^{\mathrm{d}} \\
\text { HR } 0.92^{\mathrm{d}} \\
\text { HR } 0.90^{\mathrm{d}} \\
\text { HR } 0.90^{\mathrm{d}}\end{array}$ & $\begin{array}{l}0.95-1.01 \\
0.88-1.01 \\
0.86-0.98 \\
0.84-0.99 \\
0.84-0.97\end{array}$ & $\begin{array}{l}\text { n.r. } \\
0.089 \\
0.011 \\
0.004 \\
0.005\end{array}$ \\
\hline Fan [35] & & & all patients & HR 0.98 & $0.94-1.02$ & 0.266 \\
\hline Chuang [36] & & hospital & & OR $2.94^{\mathrm{d}}$ & $1.56-5.55$ & 0.0009 \\
\hline Lacson [37] & & freestanding & & HR $0.74^{\mathrm{d}}$ & $0.56-0.89^{e}$ & 0.01 \\
\hline Bond [6] & & freestanding & & HR 1.04 & $0.97-1.12$ & n.s. \\
\hline USRDS [38] & & & $\begin{array}{l}\text { Fresenius }^{\mathrm{f}} \\
\text { DaVitag }^{\mathrm{g}} \\
\text { DCI }^{\mathrm{f}}\end{array}$ & $\begin{array}{l}\text { SMR } 1.01 \\
\text { SMR } 0.97 \\
\text { SMR } 0.96\end{array}$ & $\begin{array}{l}1.02 \\
0.99 \\
1.01\end{array}$ & $\begin{array}{l}0.99 \\
0.96 \\
0.91\end{array}$ \\
\hline
\end{tabular}

n.r. = Not reported; n.s. = not reported, but informed to be not significant.

${ }^{a}$ Results without adjustment for comorbidities. ${ }^{b}$ The results refer to the $1991-1993$ period to avoid duplication of data from Held et al. [28]. ${ }^{\mathrm{c}}$ Numerical data not reported, presented only in graphics. ${ }^{\mathrm{d}}$ Calculation of risk ratios using single use/reuse. ${ }^{\mathrm{e}}$ Data provided from contact with the corresponding author of the study. ${ }^{\mathrm{f}} 100 \%$ patients treated with single use of dialyzers. ${ }^{\mathrm{g}} \geq 75 \%$ patients treated with reuse of dialyzers. 
time-dependent covariate analysis. Statistical adjustments using linear, logistic and Cox regression can also avoid confounding effects. However, it is recognized that statistical adjustment cannot control all confounding [51]. Studies included in this review employed different adjustment models, but most results were small to moderate in size (ORs or HRs between 0.6 and 1.6), which asks for caution when interpreting results [51].

Comorbidities and other confounding factors arising from end-stage renal disease hamper the investigation of the influence of dialyzer reuse on patient mortality. In addition to preexisting comorbidities, end-stage renal disease patients have been hypothesized to have higher risk for developing cardiovascular disease, diabetes and cancer $[38,52]$.

Most studies were conducted in past decades, and conventional dialyzer use was predominant. Currently, synthetic and more biocompatible membranes are employed more often in hemodialysis therapy. First-use syndrome and other adverse effects attributed to the conventional dialyzers are less frequent [53]. Synthetic dialyzers can also lead to different degrees of biological responses, and robust evidence of the superiority of synthetic membranes versus conventional dialyzers is not available [54, 55].

Membrane permeability could represent an additional confounding factor. Based on the biological plausibility of the greater elimination of potentially harmful molecules, membrane permeability is believed to influence patient prognosis [56]. Two randomized clinical trials have shown nonsignificant lower risks of mortality in patients on hemodialysis using high-flux rather than low-flux dialyzers $[57,58]$. The first trial randomized 1,846 patients treated with standard or high dose of dialysis using a low-flux or high-flux dialyzer, and found no significant differences in the dose or flux assignment (high dose vs. standard dose: $\mathrm{RR}=0.96$; 95\% CI: 0.841.10; high-flux vs. low-flux: RR = 0.92; 95\% CI: 0.81-1.05) [57]. The more recent clinical trial assigned 738 incident hemodialysis patients to either low-flux or high-flux membranes, and found a nonsignificant mortality reduction with high-flux membrane, compared to lowflux ones (HR $=0.76$; 95\% CI: 0.56-1.04) [58]. Cohort studies that analyzed the permeability and biocompatibility of the membranes could not identify significant differences between groups either [59-61]; however, one French cohort study that investigated only permeability found better survival in patients on high-flux dialysis therapy over a long time period $(\mathrm{RR}=0.62$; 95\% CI: $0.43-$ 0.91) [62].

There is no evidence to support an effect on mortality of dialyzer reuse compared to single use in patients with end-stage renal disease. The studies included in this review assessed more than 900,000 patients without detecting significant and consistent differences in mortality risks when comparing reuse with single use. The inconclusive data regarding the effectiveness and safety of dialyzer reuse has not prevented this practice, which continues in many countries. Better methodological quality in selected studies and randomized clinical trials are required to assess the effectiveness and safety of dialyzer reuse.

\section{Acknowledgements}

We would like to thank our collaborators Alcineide Lima Magalhães, Carolina Dalene Silva, Débora Freire Galvão, Eric Oliveira Jarude Thomaz, Joice Costa de Oliveira, Joyce Fernandes, Laila Cristina Alves Rojas, Nádia Maria Soares Bezerra and Victor Braule Pinto Marques for helping in the study selection process.

This research was funded by a public research agency (Brazilian National Research Council).

\section{Disclosure Statement}

The authors declare they have no conflicts of interest.

\section{References}

1 Shaldon S, Silva H, Rosen SM: Technique of refrigerated coil preservation haemodialysis with femoral venous catheterization. BMJ 1964;2:411-413.

-2 Finelli L, Miller JT, Tokars JI, Alter MJ, Arduino MJ: National surveillance of dialysisassociated diseases in the United States, 2002. Semin Dial 2005; 18:52-61.
Tokars JI, Finelli L, Alter MJ, Arduino MJ: National surveillance of dialysis-associated diseases in the United States, 2001. Semin Dial 2004;17:310-319.

-4 Lowrie EG, Li Z, Ofsthun N, Lazarus JM: Reprocessing dialysers for multiple uses: recent analysis of death risks for patients. Nephrol Dial Transplant 2004;19:2823-2830.
Upadhyay A, Sosa MA, Jaber BL: Single-use versus reusable dialyzers: the known unknowns. Clin J Am Soc Nephrol 2007;2: 1079-1086.

-6 Bond TC, Nissenson AR, Krishnan M, Wilson SM, Mayne T: Dialyzer reuse with peracetic acid does not impact patient mortality. Clin J Am Soc Nephrol 2011;6:1368-1374. 
7 Cusumano A, Garcia GG, Di Gioia C, Hermida O, Lavorato C, Latin American Registry of Dialysis and Transplantation: The Latin American Dialysis and Transplantation Registry (RLDT) annual report 2004. Ethn Dis 2006;16:S2-10-13.

8 Jha V: Current status of end-stage renal disease care in South Asia. Ethn Dis 2009;19:S127-32.

-9 National Kidney Foundation Report on Dialyzer Reuse. Task Force on Reuse of Dialyzers, Council on Dialysis, National Kidney Foundation. Am J Kidney Dis 1997;30:859871.

10 Vinhas J, Pinto dos Santos J: Haemodialyser reuse: facts and fiction. Nephrol Dial Transplant 2000;15:5-8.

-11 Klefter R, Nielsen B: Savings in dialysis treatment? Artif Organs 2002;26:49-54.

-12 Lacson E, Lazarus JM: Dialyzer best practice: single use or reuse? Semin Dial 2006;19: 120-128.

13 Twardowski ZJ: Dialyzer reuse. II. Advantages and disadvantages. Semin Dial 2006; 19:217-226

14 Balshem $\mathrm{H}$, Helfand M, Schünemann HJ, Oxman AD, Kunz R, Brozek J, Vist GE, Falck-Ytter Y, Meerpohl J, Norris S, Guyatt GH: GRADE guidelines. 3. Rating the quality of evidence. J Clin Epidemiol 2011;64: 401-406.

- 15 Vanholder R, Ringoir S: Influence of reuse and of reuse sterilants on the first-use syndrome. Artif Organs 1987;11:137-139.

-16 Sherman RA, Cody RP, Rogers ME, Solanchick JC: The effect of dialyzer reuse on dialysis delivery. Am J Kidney Dis 1994;24:924926.

- 17 Manandhar DN, Chhetri PK, Tiwari R, Lamichhane S: Evaluation of dialysis adequacy in patients under hemodialysis and effectiveness of dialysers reuses. Nepal Med Coll J 2009;11:107-110.

- 18 Wing AJ, Brunner FP, Brynger HO, Chantler C, Donckerwolcke RA, Gurland HJ, Jacobs C, Selwood NH: Mortality and morbidity of reusing dialysers. A report by the registration committee of the European dialysis and transplant association. BMJ 1978;2:853-855.

19 Pollak VE, Kant KS, Parnell SL, Levin NW: Repeated use of dialyzers is safe: long-term observations on morbidity and mortality in patients with end-stage renal disease. Nephron 1986;42:217-223.

20 Sandler SG, Sharon R, Stessman J, Czaczkes JW: Antiformaldehyde and anti-n-like antibodies in hemodialysis patients. Isr J Med Sci 1978; 14:1177-1180.

-21 Man NK, Lebkiri B, Polo P, de Sainte-Lorette E, Lemaire A, Funck-Brentano JL: Prevention of anti-n like antibodies development with nonformaldehyde reuse procedure. Proc Clin Dial Transplant Forum 1980;10: $18-21$.
22 Pereira BJ, Natov SN, Sundaram S, Schmid $\mathrm{CH}$, Trabelsi FR, Strom JA, King AJ: Impact of single use versus reuse of cellulose dialyzers on clinical parameters and indices of biocompatibility. J Am Soc Nephrol 1996;7: 861-870.

23 Cheung AK, Agodoa LY, Daugirdas JT, Depner TA, Gotch FA, Greene T, Levin NW, Leypoldt JK: Effects of hemodialyzer reuse on clearances of urea and beta2-microglobulin. The Hemodialysis (HEMO) Study Group. J Am Soc Nephrol 1999;10:117-127.

24 Rao M, Guo D, Jaber BL, Sundaram S, Cendoroglo M, King AJ, Pereira BJ, Balakrishnan VS, Group HS: Dialyzer membrane type and reuse practice influence polymorphonuclear leukocyte function in hemodialysis patients. Kidney Int 2004;65:682-691.

-25 Feldman HI, Bilker WB, Hackett M, Simmons CW, Holmes JH, Pauly MV, Escarce JJ: Association of dialyzer reuse and hospitalization rates among hemodialysis patients in the US. Am J Nephrol 1999;19:641-648.

26 Kant KS, Pollak VE, Cathey M, Goetz D, Berlin R: Multiple use of dialyzers: safety and efficacy. Kidney Int 1981;19:728-738.

27 Held PJ, Pauly MV, Diamond L: Survival analysis of patients undergoing dialysis. JAMA 1987;257:645-650.

28 Held PJ, Wolfe RA, Gaylin DS, Port FK, Levin NW, Turenne MN: Analysis of the association of dialyzer reuse practices and patient outcomes. Am J Kidney Dis 1994;23: 692-708.

29 Feldman HI, Kinosian M, Bilker WB, Simmons C, Holmes JH, Pauly MV, Escarce JJ: Effect of dialyzer reuse on survival of patients treated with hemodialysis. JAMA 1996;276:620-625.

30 Collins AJ, Ma JZ, Constantini EG, Everson SE: Dialysis unit and patient characteristics associated with reuse practices and mortality: 1989-1993. J Am Soc Nephrol 1998;9: 2108-2117.

31 Feldman HI, Bilker WB, Hackett MH, Simmons CW, Holmes JH, Pauly MV, Escarce JJ: Association of dialyzer reuse with hospitalization and survival rates among U.S. hemodialysis patients: do comorbidities matter? J Clin Epidemiol 1999;52:209-217.

32 Ebben JP, Dalleska F, Ma JZ, Everson SE, Constantini EG, Collins AJ: Impact of disease severity and hematocrit level on reuseassociated mortality. Am J Kidney Dis 2000; 35:244-249.

33 Port FK, Wolfe RA, Hulbert-Shearon TE, Daugirdas JT, Agodoa LY, Jones C, Orzol SM, Held PJ: Mortality risk by hemodialyzer reuse practice and dialyzer membrane characteristics: results from the USRDS dialysis morbidity and mortality study. Am J Kidney Dis 2001;37:276-286.

34 Collins AJ, Liu J, Ebben JP: Dialyser reuseassociated mortality and hospitalization risk in incident medicare haemodialysis patients, 1998-1999. Nephrol Dial Transplant 2004 19:1245-1251.
35 Fan Q, Liu J, Ebben JP, Collins AJ: Reuse-associated mortality in incident hemodialysis patients in the United States, 2000 to 2001. Am J Kidney Dis 2005;46:661-668.

36 Chuang FR, Lee CH, Chang HW, Lee CN, Chen TC, Chuang $\mathrm{CH}$, Chiou TT, Wu CH, Yang CC, Wang IK: A quality and cost-benefit analysis of dialyzer reuse in hemodialysis patients. Ren Fail 2008;30:521-526.

37 Lacson E, Wang W, Mooney A, Ofsthun N, Lazarus JM, Hakim RM: Abandoning peracetic acid-based dialyzer reuse is associated with improved survival. Clin J Am Soc Nephrol 2011;6:297-302.

38 US Renal data system. USRDS 2011 annual data report: Atlas of Chronic Kidney Disease and End-Stage Renal Disease in the United States. Bethesda, National Institutes of Health, National Institute of Diabetes and Digestive and Kidney Diseases, 2011.

39 Erek E, Sever MS, Akoglu E, Sariyar M, Bozfakioglu S, Apaydin S, Ataman R, Sarsmaz N, Altiparmak MR, Seyahi N, Serdengecti K: Cost of renal replacement therapy in Turkey. Nephrology (Carlton) 2004;9:33-38

40 Mahdavi-Mazdeh M, Zamani M, Zamyadi M, Rajolani H, Tajbakhsh K, Heidary Rouchi A, Aghighi M, Mahdavi A: Hemodialysis cost in Tehran, Iran. Hemodial Int 2008; 12 : 492-498.

41 Fabrizi F, Messa P, Martin P: Transmission of hepatitis $\mathrm{C}$ virus infection in hemodialysis: current concepts. Int J Artif Organs 2008; 31:1004-1016.

42 Churchill DN, Taylor DW, Shimizu AG, Beecroft ML, Singer J, Barnes CC, Ludwin D, Wright N, Sackett DL, Smith EK: Dialyzer re-use - a multiple crossover study with random allocation to order of treatment. Nephron 1988;50:325-331.

43 Medicare program; standards for quality of water used in dialysis and revised guidelines on reuse of hemodialysis filters for end-stage renal disease (ESRD) patients - HCFA. Final rule. Fed Regist 1995;60:48039-48044.

44 Association for the Advancement of Medical Instrumentation. AAMI Recommended Practice. ANSI/aAMI Rd47:2008, Reprocessing of Hemodialyzers, 2008.

-45 Scott MK, Mueller BA, Sowinski KM, Clark WR: Dialyzer-dependent changes in solute and water permeability with bleach reprocessing. Am J Kidney Dis 1999;33:87-96.

46 Demets DL: The role of surrogate outcome measures in evaluating medical devices. Surgery 2000;128:379-385.

47 Slyby T, Huff G, Henger MJ: Dialyzer reprocessing: improved treatment quality and increased dialyzer reuse using a team approach. Nephrol Nurs J 2000;27:483-488.

$\checkmark 48$ Okechukwu CN, Orzol SM, Held PJ, Pereira BJ, Agodoa LY, Wolfe RA, Port FK: Characteristics and treatment of patients not reusing dialyzers in reuse units. Am J Kidney Dis 2000;36:991-999. 
49 Suissa S: Immortal time bias in pharmacoepidemiology. Am J Epidemiol 2008;167: 492-499.

50 Liu J, Weinhandl ED, Gilbertson DT, Collins AJ, St Peter WL: Issues regarding 'immortal time' in the analysis of the treatment effects in observational studies. Kidney Int 2011;81: 341-350.

51 Sainani K: The limitations of statistical adjustment. PMR 2011;3:868-872.

-52 Wong G, Hayen A, Chapman JR, Webster AC, Wang JJ, Mitchell P, Craig JC: Association of CKD and cancer risk in older people. J Am Soc Nephrol 2009;20:1341-1350.

53 Ouseph R, Jones S, Dhananjaya N, Ward RA: Use of ultrafiltered dialysate is associated with improvements in haemodialysis-associated morbidity in patients treated with reused dialysers. Nephrol Dial Transplant 2007;22:2269-2275.

54 Macleod AM, Campbell M, Cody JD, Daly C, Donaldson C, Grant A, Khan I, Rabindranath KS, Vale L, Wallace S: Cellulose, modified cellulose and synthetic membranes in the haemodialysis of patients with end-stage renal disease. Cochrane Database Syst Rev 2005;CD003234.
55 Alonso A, Lau J, Jaber BL: Biocompatible hemodialysis membranes for acute renal failure. Cochrane Database Syst Rev 2008;CD005283.

56 Cheung AK, Greene T: Effect of membrane permeability on survival of hemodialysis patients. J Am Soc Nephrol 2009;20:462-464.

57 Eknoyan G, Beck GJ, Cheung AK, Daugirdas JT, Greene T, Kusek JW, Allon M, Bailey J, Delmez JA, Depner TA, Dwyer JT, Levey AS, Levin NW, Milford E, Ornt DB, Rocco MV, Schulman G, Schwab SJ, Teehan BP, Toto R, Group HHS: Effect of dialysis dose and membrane flux in maintenance hemodialysis. N Engl J Med 2002;347:2010-2019.

58 Locatelli F, Martin-Malo A, Hannedouche T, Loureiro A, Papadimitriou M, Wizemann V, Jacobson SH, Czekalski S, Ronco C, Vanholder R, Group MPOMS: Effect of membrane permeability on survival of hemodialysis patients. J Am Soc Nephrol 2009;20: 645-654.
59 Yokoyama H, Kawaguchi T, Wada T, Takahashi Y, Higashi T, Yamazaki S, Fukuhara S, Akiba T, Akizawa T, Asano Y, Kurokawa K, Saito A, Group J-DR: Biocompatibility and permeability of dialyzer membranes do not affect anemia, erythropoietin dosage or mortality in Japanese patients on chronic non-reuse hemodialysis: a prospective cohort study from the J-DOPPS II study. Nephron Clin Pract 2008;109:c100-c108.

60 Krane V, Krieter DH, Olschewski M, März W, Mann JF, Ritz E, Wanner C: Dialyzer membrane characteristics and outcome of patients with type 2 diabetes on maintenance hemodialysis. Am J Kidney Dis 2007; 49:267-275.

61 Götz AK, Böger CA, Popal M, Banas B, Krämer BK: Effect of membrane flux and dialyzer biocompatibility on survival in endstage diabetic nephropathy. Nephron Clin Pract 2008;109:c154-c160.

62 Chauveau P, Nguyen H, Combe C, Chêne G, Azar R, Cano N, Canaud B, Fouque D, Laville M, Leverve X, Roth H, Aparicio M, Dialysis FSGfNi: Dialyzer membrane permeability and survival in hemodialysis patients. Am J Kidney Dis 2005;45:565-571. 